\title{
Contribution of the atmospheric channel to lead contamination of soils in the Arctic territories
}

\author{
EI Kotova $^{1}$, IA Kuznetsova ${ }^{1}$, VV Kriauciunas ${ }^{1}$, SA Iglovsky ${ }^{1}$, NS Larionov ${ }^{1}$ \\ 1 N. Laverov Federal Centre for Integrated Studies of the Arctic (Arkhangelsk, Russian Federation) \\ Corresponding author: Irina A. Kuznetsova (kia.iepn@gmail.com)
}

Academic editor: Aleksandr I. Malov • Received 14 June 2019 • Accepted 17 June 2019 • Published 5 July 2019

Citation: Kotova EI, Kuznetsova IA, Kriauciunas VV, Iglovsky SA, Larionov NS (2019) Contribution of the atmospheric channel to lead contamination of soils in the Arctic territories. Arctic Environmental Research 19(2): 56-64. https://doi. org/10.3897/issn2541-8416.2019.19.2.56

\begin{abstract}
Although the Arctic territories have long been considered "the gold standard of purity", global climate change and environmental pollution are having a significant impact on the state of Arctic ecosystems. In particular, industrial complexes combined with transboundary transport are having a negative impact. The aim of this work is to determine the contribution of atmospheric $\mathrm{Pb}$ to the contamination of soils of the Arctic territories using the trajectory statistics method which combines correlation and factor statistical processing approaches while taking the actual lead content in the upper soil horizon into account. In order to assess the transfer of pollutants, an analysis of multiannual air mass tracts and impurity transfer trajectories to certain points was carried out. The objects of study are the soil of the Khorey-Ver settlement, the basin of the Shapkin and Sula rivers, northeastern and southern Svalbard and the islands of the Southern Archipelago of Novaya Zemlya. It was established that the primary contribution to airborne pollution of the Nenets Autonomous District (NAO) during the summer period comes from sources located within a radius of about $400 \mathrm{~km}$. Aerogenic influence of the mainland on the territory of Svalbard is practically absent, with the main atmospheric transport of substances coming from nearby marine areas. The transfer of impurities from the mainland to the Novaya Zemlya District is also insignificant. During the summer months, there is practically no airborne lead contamination of the island territories. Some influences on the territory of Novaya Zemlya and the NEO can be traced to sources on the Kola Peninsula, the coasts of the Barents and Kara seas, as well as long-distance transport from the southern regions. On the territory of the NAO, the number of heavy metal (HM) precipitations increases from west to east, possibly indicating a stronger impact of emissions from the Norilsk industrial hub than from the enterprises of the Kola Peninsula on this territory. In terms of seasonal dynamics, the island points are characterised by an increase in HM fluxes during the winter period; conversely, for the NAO territory, such an increase takes place during the summer. This discrepancy is primarily due to the changing nature of the atmospheric circulation.
\end{abstract}

Copyright Kotova El et al. This is an open access article distributed under the terms of the Creative Commons Attribution License (CC-BY 4.0), which permits unrestricted use, distribution, and reproduction in any medium, provided the original author and source are credited. 


\section{Keywords}

lead, soil, Arctic Region, atmospheric transport

\section{Introduction}

The impact of global climate change and environmental pollution on the state of the oceanic and marine ecosystems, as well as on land-based bodies of water, is especially significant in the Arctic territories. Until recently, the state of the Arctic territories was considered as a "gold standard of purity". At the present time, the northern regions of Eurasia can be very conditionally considered as background in terms of anthropogenic impact on their environment. Both the long-range transport of anthropogenic pollution and the presence of powerful industrial complexes in the Arctic itself are having an impact. Despite the fairly large number of individual publications and reviews devoted to this issue (Vinogradova and Ivanova 2017, Vinogradova et al. 2008, Hirdman et al. 2010), the study of anthropogenic impact, transmitted through the atmosphere, on the environment of the northern regions of Russia remains highly relevant.

The aim of this work is to determine the contribution of atmospheric $\mathrm{Pb}$ to the contamination of soils of the Arctic territories using the trajectory statistics method.

\section{Materials and methods}

To date, there are a large number of methods for mathematical modelling of direct and inverse problems in mathematical physics, including problems of contaminant transfer.

A number of models have already been developed that describe processes of emission, distribution and neutralisation of polluting aerosol substances in atmospheric air. All of them, in one form or another, rely on the law of conservation of mass and use grid methods to solve the corresponding equation (Berlyand 1985, Marchuk 1982, Olshan- sky 2004). Such models implemented in the form of computer systems offer a quite effective means of calculating the atmospheric dispersion of pollutants (Belikhov 2013).

When using mathematical modelling methods for the formulation of a direct problem, the investigated physical phenomenon is described by partial differential equations with the corresponding initial and boundary conditions.

Three-dimensional hydrodynamic models are typically used for assessing the transfer of contaminants over a complex underlying surface (Gavrilov et al. 2010). On the basis of such models, pollutant trajectories can be constructed that take expected weather conditions, wind speed and direction in the atmospheric boundary layer into account (Belov and Karlova 1990). One such approach developed at ICMMG SB RAS (Pianova et al. 2017) presented a numerical mesoscale non-hydrostatic model of atmospheric dynamics and impurity transport, comprising a complex of computational modules and programs.

The acronym LDPM (Lagrangian particle dispersion models) is used in the literature to describe the method of calculating turbulent diffusion on the basis of random trajectories of elements of atmospheric turbulence. The best-known models for calculating deterministic trajectories are implemented in the FLEXTRA (NILU) and HYSPLIT (NOAA) programs accessible via the Internet (Ivakhov and Zinchenko 2012).

In order to calculate the return trajectories, the HYSPLIT4 model was used in combination with data from the reanalysis of NCEP / NCAR meteorological elements (Draxler and Rolph 2013); this standard approach has already been used in many studies (Panov et al. 2011, Netsvetaeva et al. 2013, Vinogradova et al. 2008).

For six selected points (Fig. 1), 5-day return trajectories were calculated, through which air enters 


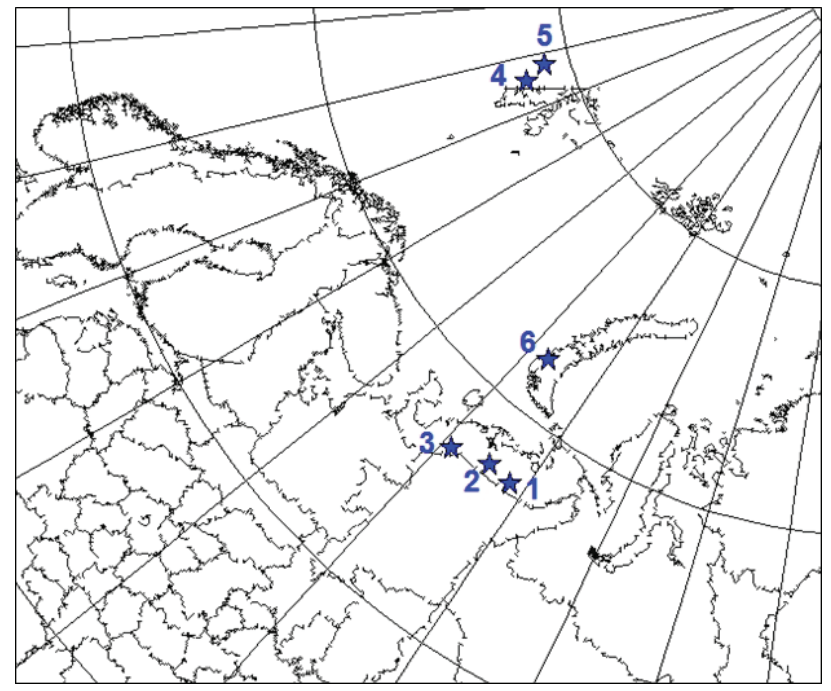

Fig. 1. Location of calculated points: T. $1-$ Khorey-Ver, T. 2 - Shapkino, T. 3 - Sula, T. 4 - NW Svalbard, T. 5 - South Svalbard, T. 6 - Novaya Zemlya

the respective points at 0 hours UTC (calculation interval 1 hour).

The calculation was carried out for the winter and summer periods between 2010 and 2015.

Our calculations of long-range pollution transport in the Arctic are based on the statistical air mass trajectory method, which has been widely used in similar studies (Hirdman et al. 2010, Salvador et al. 2010, Vinogradova and Ponomareva 2012, Vinogradova 2015).

In recent years, the method of analysing the trajectories of air masses has been used not only to study the composition and genesis of specific air samples taken during experimental work, but also to study the average regularities in the processes of long-range air transport and its components in the atmosphere (Stohl 1998, Polissar et al. 1998, Malyshkin et al. 2007, Surkova et al. 2010, Salvador et al. 2010, Golubeva et al. 2010).

The basis of the approach used in this work is the analysis of multiannual arrays of air-mass and pollutant transfer trajectories to an arbitrary geographic location, the methodology of which was originally developed at the IFA RAS and improved over recent years (Vinogradova 2015). This methodology, which has been tested over the course of carrying out assessments on different territories, is capable of pro- viding unique information that does not contradict the results of other scientific works and assessments (Vinogradova et al. 2008, Vinogradova and Ivanova 2017, Vinogradova and Kotova 2016).

The modelling of the distribution of contaminants during their long-range atmospheric transport is performed similarly to that detailed in the works (Vinogradova 2000, Galperin et al. 1995, Rovinsky et al. 1994). Here, it is assumed that the transferred contamination is chemically passive and that the atmospheric transfer of contaminants involves aerosol particles of submicron size.

On the grid $\left(1^{\circ} \times 1^{\circ}\right)$, the function $Z_{i j}(X)$ was calculated for each cell with coordinates (ij) - a function of potential sources characterising all atmospheric processes determining the transfer of impurity $X$ from a source $m$ to point $n$ : probability, duration, range, vertical deposition on the surface and horizontal spreading.

The value $\mathrm{Z}_{\mathrm{ij}}$ is calculated according to (Vinogradova 2015):

$$
Z_{i j}=\frac{n_{i j} t_{i j} * \exp \left(-\frac{K_{i j} t_{i j}}{h_{i j}}\right)}{2 \pi N b h_{i j} L_{i j}{ }^{2}},
$$

where $\mathrm{n}_{\mathrm{ij}}$ - the number of trajectory points in the cell; $t_{i j}$ - the average time of air movement from a given cell to the point of observation; $h_{i j}$ - the average height of the layer of mixing, calculated along the trajectories of air from the cell to the point of observation; $\mathrm{L}_{\mathrm{ij}}$ the average length of these trajectories; $\mathrm{N}$ - the total number of points of daily trajectories for the billing period; $b$ - the coefficient of expansion of the air flux in the horizontal direction $(\mathrm{b} \approx 0.15) ; \mathrm{K}_{\mathrm{ij}}$ - the average sedimentation velocity of the impurity on the surface as it moves from the cell to the observation point, which is chosen as the average of two values - for the cell (ij) and for the observation point cell.

It is assumed that the admixture is distributed uniformly in the vertical dimension within the surface mixing layer, whose height is calculated

simultaneously with the trajectories using the HYSPLIT4 model and then averaged over $h_{\mathrm{ij}}$.

The parameters of the rate of removal of contaminants from the airstream are presented in (Vinogra- 
dova 2015). These correspond approximately to the classical climatic zoning of the territory.

As indicators of environmental pollution, $\mathrm{Pb}$ fluxes to the surface were calculated, consisting of chemically passive (along the transfer path) contaminants transported over long distances predominantly on aerosol particles of submicron size.

Data on emissions of lead into the atmosphere from Europe were selected from the EMEP database, which is accessible for interactive use via the Internet (EMEP 2019). The database contains all information on anthropogenic emissions of lead and cadmium officially presented by the secretariat of the Convention on Long-range Transboundary Air Pollution and parties to the Convention.

Within the framework of field studies, soil samples were selected from 75 sample areas in the territories shown in Fig. 1 in the period from 2013 to 2017 (Evolution ... 2016, 2017). Preparation of the samples for analysis included drying them to an air-dry state, separating large mineral inclusions and undecomposed mineral residues and grinding samples in a RM 100 planetary ball mill at $400 \mathrm{rpm}$ to a fraction of about 70 microns. For instrumental analysis, a working sample was taken from the ground sample by quartering it.

The average lead content (in terms of $\mathrm{mg} \mathrm{Pb}$ per $\mathrm{kg}$ of soil absolute dry weight.) In the upper soil layer was obtained from the results of X-ray fluorescence analysis of soil samples using a specialised technique (Methodology ... 2009)

Statistical data processing was carried out using software from StatSoft Inc. (2011). STATISTICA (data analysis software system), version 10. www.statsoft.com.

Statistical data processing consisted in establishing significant correlations between the considered parameters of the objects of study. Factor analysis using study.

\section{Results}

The spatial distribution of the function $Z_{i j}(X)$, reflecting the degree of influence of anthropogenic sources of pollution on the territories under consideration, is presented in Figures 2-4.

The average heavy metal (HM) fluxes to the surface, which were calculated taking the emission of metal sources into account, formed the basis for calculating pair correlations, factor analysis and plotting the average lead content in the soil and fluxes given in Table 1.

Paired correlations between the average lead content in soils and fluxes are shown in Table 2; the results of the factor analysis are shown in Table 3.

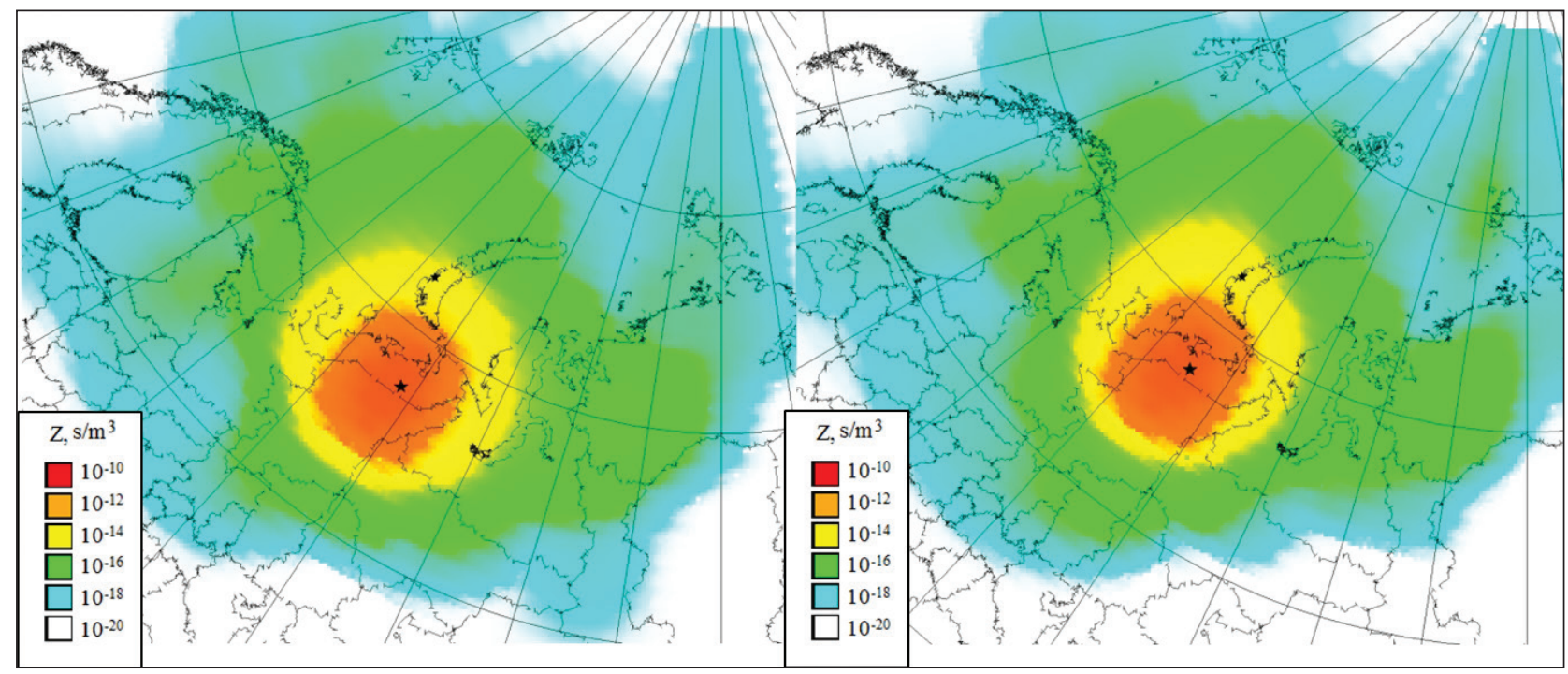

Fig. 2. Spatial distribution of function $\mathrm{Z}$ in July for points 1-2 


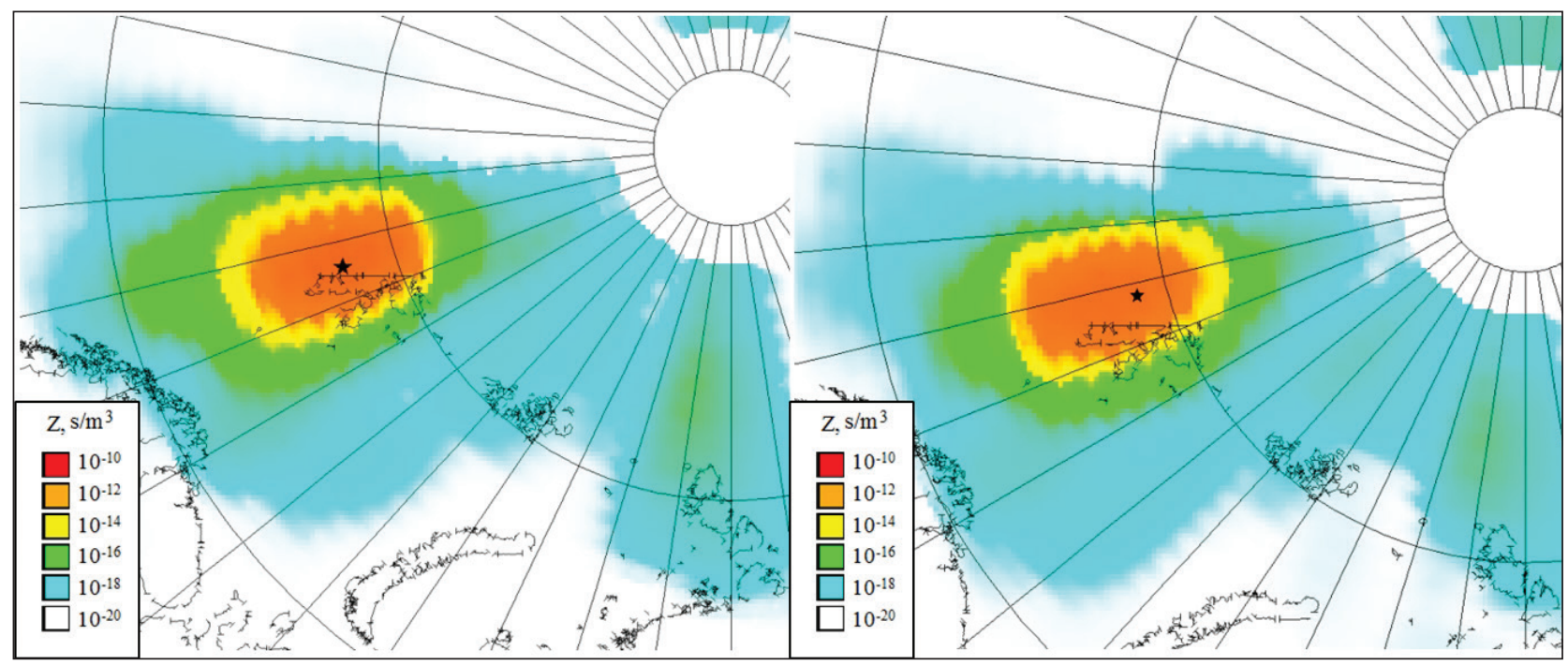

Fig. 3. Spatial distribution of function $\mathrm{Z}$ in July for points 4-5

Table 1. Fluxes and average lead content in the soils of the studied territories

\begin{tabular}{lccc}
\hline \multicolumn{1}{c}{ Territory } & \multicolumn{2}{c}{ Pb fluxes, } \\
& $\begin{array}{c}\text { mkg.km } \\
\text { Winter }\end{array}$ & Summer $^{-1}$ & $\begin{array}{c}\text { Mean Pb concentration } \\
\text { for surface soils, } \\
\text { mg.kg-1 }\end{array}$ \\
\hline Khorey-ver & 30.54 & 51.41 & 11.88 \\
Shapkino & 32.82 & 31.20 & 9.57 \\
Sula & 21.68 & 11.45 & 5.41 \\
Northeast Svalbard & 18.78 & $5.55 \cdot 10^{-5}$ & 2.47 \\
South Svalbard & 13.59 & $2.03 \cdot 10^{-6}$ & 2.47 \\
Novaya Zemlya & 3.96 & $95.19 \cdot 10^{-3}$ & 6.15 \\
\hline
\end{tabular}

Table 2. Paired correlations

\begin{tabular}{lcc}
\hline & \multicolumn{2}{c}{ Pb fluxes } \\
\cline { 2 - 3 } & Winter & Summer $\mathbf{P b}$ \\
\hline Average $\mathrm{Pb}$ content in soils & $0.6453, \mathrm{p}=0.166$ & $\mathbf{0 . 9 3 2 8 , \mathbf { p } = \mathbf { 0 . 0 0 7 }}$ \\
\hline
\end{tabular}

Table 3. Results of factor analysis

\begin{tabular}{lccc}
\hline & Factor $\mathbf{1}$ & Factor 2 & Factor 3 \\
\hline $\mathrm{Pb}$ flux winter & $\mathbf{0 . 7 5}^{*}$ & 0.00 & 0.66 \\
$\mathrm{~Pb}$ flux summer & $\mathbf{0 . 9 3}$ & 0.32 & 0.19 \\
Average $\mathrm{Pb}$ content in soils & $\mathbf{0 . 7 8}$ & 0.60 & 0.11 \\
Explained Variance & 6.88 & 4.87 & 2.19 \\
Proportion of Total Variance & 0.49 & 0.35 & 0.16 \\
\hline
\end{tabular}

Note: Marked loads $>0.70$.
Significant correlations of lead content in soils with $\mathrm{p}<0.01$ with fluxes in the summer period should be noted.

The graph of average lead content in soils versus flux during the summer period is shown in Figure 5.

The spatial distribution of the function $\mathrm{Zij}(\mathrm{X})$ (Figures 2-4) makes it possible to identify areas that are particularly significant from the perspective of environmental pollution at the considered point where anthropogenic sources of air pollution are located. The values $Z_{i j}(X)$ show the correspondence of the potential of sources located at different geographical points to introduce pollution into the environment of the observation point.

As seen in Figures 2, 4, the spatial distribution of the values of the function $\mathrm{Z}$ in July is analogous to that for closely spaced points $1-3$. The main contribution to the airborne pollution of the territories in the summer period is made by anthropogenic sources located within a radius of about $400 \mathrm{~km}$ : the north of the Komi Republic, the Nenets Autonomous District, offshore areas - as well as, for Point 3, the northeast of the Arkhangelsk region. Aerogenic influence of the mainland on the territory of Svalbard (Fig. 3) is practically absent, with the main atmospheric transport of substances coming from nearby marine areas. The transfer of impurities from the mainland to the Nova- 


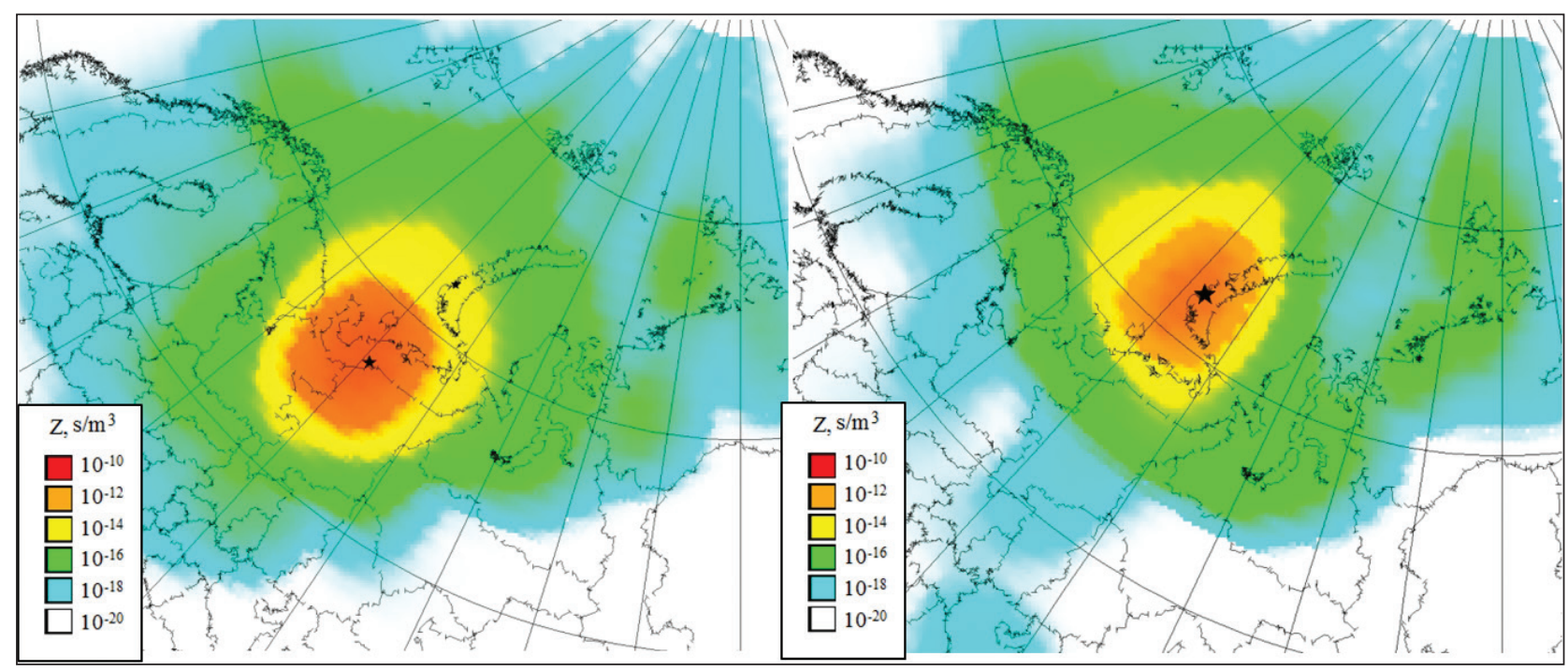

Fig. 4. Spatial distribution of function $\mathrm{Z}$ in July for points 3, 6

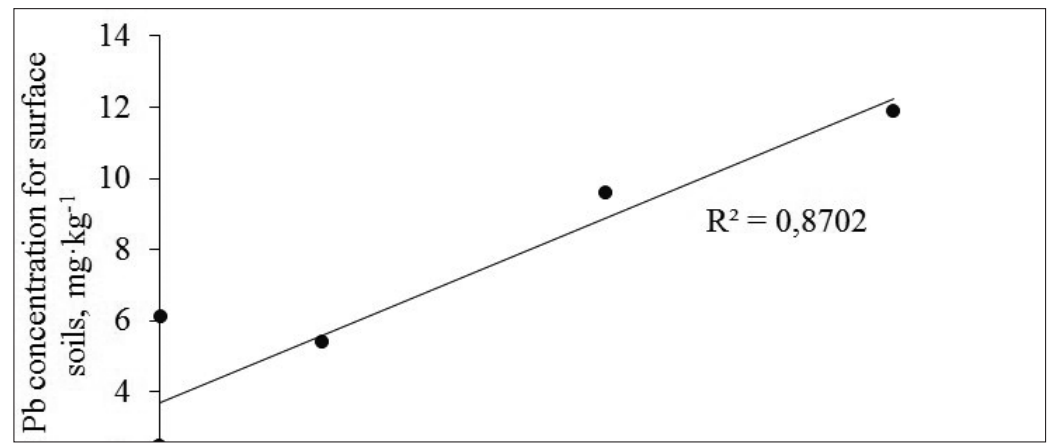

Fig. 5. Graph of average lead content in soils versus flux during the summer period.

ya Zemlya District (Fig. 4) is also insignificant. At the same time, some influence of sources from the Kola Peninsula, the coast of the Barents and Kara Seas on the territory of Novaya Zemlya, as well as on points located in the Nenets Autonomous District (NAO), can also be traced. A contribution of long-range transport from the southern regions is also made to the airborne pollution of the NAO and Novaya Zemlya territories.

The obtained calculations are consistent with the data of Roshydromet on the burden of atmospheric precipitation of lead in the area (Review... 2011).

According to the calculations, the minimum delivery of lead pollutants, both in the summer and in the winter periods, is expected to enter the territory of the Novaya Zemlya archipelago. During the summer months, there is practically no airborne lead contamination of the island territories.

On the territory of the NAO, the quantity of lead precipitation increases from west to east, possibly indicating a stronger impact of emissions from the Norilsk industrial hub than from the Kola Peninsula on this territory.

In terms of seasonal dynamics, the island points are characterised by an increase in HM fluxes during the winter period; conversely, for the NAO territory, such an increase takes place during the summer. This may be due to the summer contribution of the wind uplift of lead in the composition of fine fractions of eroded 
soils (terrigenous component), as well as a change in the character of the atmospheric circulation.

Correlation analysis of data on lead fluxes and data on its average content in the soil of the studied territories showed that the summer flux makes a significant contribution (Table 2, Figure 5).

Factor analysis using the varimax method allowed three factors to be identified, of which only the first $(49 \%)$ is closely related to lead fluxes in the summer and winter months, playing a significant role in the formation of the soil composition of the studied territories (Table 3). This factor most likely reflects the processes of deposition of lead-containing suspensions on the surface. The second and third factors, which do not make a significant contribution to lead contamination of the soils of the studied territories, may reflect the processes of atmospheric circulation and the influence of distant sources.

\section{Conclusion}

It is established that the primary contribution to airborne pollution of the NAO during the summer period comes from sources located within a radius of about $400 \mathrm{~km}$. During the summer, aerogenic influence from the mainland onto the territory of Svalbard is practically absent, with the main atmo-

\section{References}

- Belikhov AB, Legotin DL, Sukhov AK (2013) Computer simulation of atmospheric pollutants diffusion by SILAM system. Bulletin of the KSU 1: 14-19. https://elibrary.ru/item. asp?id=21270942

- Belov PN, Karlova ZL (1990) Trajectory model of pollution transfer. Meteorology and Hydrology 12: 67-74.

- Berlyand MYe (1985) Forecast and Regulation of Air Pollution. Gidrometeoizdat, Leningrad, $271 \mathrm{pp}$.

- Draxler RR, Rolph GD (2013) HYSPLIT (HYbrid Single-Particle Lagrangian Integrated Trajectory) Model, NOAA Air Resources Laboratory, College Park, MD. http://www.arl.noaa. gov/HYSPLIT.php spheric transport of substances coming from nearby marine areas. The transfer of impurities from the mainland to the Novaya Zemlya District is also insignificant. Therefore, there is practically no airborne lead contamination of the island territories during the summer months. At the same time, some influence of sources from the Kola Peninsula, the coast of the Barents and Kara Seas on the territory of Novaya Zemlya and NAO, can also be traced. A contribution of long-range transport from the southern regions is also made to the airborne pollution of the NAO and Novaya Zemlya territories. On the territory of the NAO, the quantity of lead precipitation increases from west to east, possibly indicating a stronger impact of emissions from the Norilsk industrial hub than from the Kola Peninsula on this territory. In terms of seasonal dynamics, island points are characterised by an increase in lead fluxes in winter due to the addition of remote sources. In the case of the NAO, this factor is present during the summer season due to dust and soil contributions.

The present work was carried out with the financial support of a grant for the implementation of the state task "Complex isotope-geochemical studies of the quality of the environment and identification of its transformation processes in the coastal territories of the European North both present and past" (No. AAAA-A19-119011890018-3).

- EMEP (2019) Centre on Emission Inventories and Projections (CEIP). http://webdab1.umweltbundesamt.at/scaled_country_year.html?cgiproxy_skip=1

- Galperin M, Sofiev M, Gusev A, Afinogenova O (1995) Approaches to modeling transboundary atmosphere pollution of Europe with heavy metals. Report 7/95. EMEP / MSC-E, Moscow. 85 pp.

- Gavrilov KA, Morvan D, Accary G, Lyubimov DV, Meradji S, Bessonov OA (2010) Numerical modeling of coherent structures during admixture propagation in atmospheric boundary layer over forest canopy. Computing mechanics of continuous media 3(2): 34-45. https://doi.org/10.7242/1999-6691/2010.3.2.15 
- Golubeva NI, Burtseva LV, Ginzburg VA (2010) Heavy metals in the atmospheric precipitation on the Barents Sea coast. Russian Meteorology and Hydrology 35: 333. https://doi. org/10.3103/S1068373910050055

- Hirdman D, Sodemann H, Eckhardt S, Burkhart JF, Jefferson A, Mefford T, Quinn PK, Sharma S, Strom J, Stohl A (2010) Source identification of short-lived air pollutants in the Arctic using statistical analysis of measurement data and particle dispersion model output. Atmospheric Chemistry and Physics 10: 669-693. https://doi.org/10.5194/acp-10-669-2010

- Ivakhov VM, Zinchenko AV (2012) Determination of the most representative backwards trajectories depending on its specified arrival heights. Proceedings of the Main Geophysical Observatory named A.I. Voeikov. 565: 263-277. https:// elibrary.ru/item.asp?id=18122980

- Malyshkin AV, Poddubny VA, Markelov YuI, Beresnev SA, Gorda SYu, Sakerin SM, Smirnov AV (2007) Middle Ural in the AEROSIBNET: the preliminary analysis of the influence of regional sources of atmosphere aerosol pollution. Atmos. Ocean Opt. 20. No 6. 497-500.

- Marchuk GI (1982) Mathematical Modeling in the Environmental Problem. Science, Moscow, 320 pp.

- Netsvetaeva OG, Chipanina EV, Obolkin VA, Zimnik EA, Sez'ko NP, Lopatina IN, Khodzher TV (2013) Peculiarities of chemistry of atmospheric precipitations at stations Listvyanka (Irkutsk region) and Primorskaya (Primorye territory). Optika Atmosfery i Okeana. V. 26. No. 06: 466-471. https://elibrary.ru/item.asp?id=19040777

- Olshansky MA (2004) Analysis of the multigrid method for convection- diffusion equations with Dirichlet boundary conditions. Journal of Computational Mathematics and Mathematical Physics 44(8): 1450-1479.

- Panov AV, Zrazhevskaya GK, Timokhina AV, Onuchin AA, Heintzenberg J, Birmili W, Otto R, Chi X, Andrea M, Verkhovets SV (2011) Sources, seasonal variability, and trajectories of atmospheric aerosols over central siberian forest ecosystems. Doklady Earth Sciences 441: 1710. https://doi. org/10.1134/S1028334X1112018X

- Polissar AV, Hopke PK, Harris JM, Bodhaine BA, Dutton EG (1998) Source regions for atmospheric aerosol measured in the Western Arctic. Journal of Aerosol Science 29(Suppl. 1): 513-514. https://doi.org/10.1016/S0021-8502(98)00177-3

- Pyanova EA, Penenko VV, Faleichik LM (2017) Numerical study of the processes of atmospheric transport of impurities over the territory of urban agglomeration in a complex orography. Interexpo Geo-Siberia 2 4(1): 82-87.

- Review of environmental pollution in the Russian Federation in 2000 (2001) Feder. Russia's Hydrometeorology and Environmental Monitoring Service, 311 pp.

- Rovinsky FYa, Gromov SA, Burtseva LV, Paramonov SG (1994) Heavy metals: long-range transport in the atmosphere and precipitation with precipitation. Meteorology and $\mathrm{Hy}-$ drology 10: 5-14.

- Salvador P, Artiñano B, Pio C, Afonso J, Legrand M, Puxbaum H, Hammer S (2010) Evaluation of aerosol sources at European high altitude background sites with trajectory statistical methods. Atmosph. Environ 44(19): 2316-2329. https://doi. org/10.1016/j.atmosenv.2010.03.042

- Stohl A (1998) Computation, accuracy and applications of trajectories - A review and bibliography. Atmospheric Environment 32(6): 947-966. https://doi.org/10.1016/S1352-2310(97)00457-3

- Surkova GV, Eremina ID, Mordkovich PA (2010) On the effect of large-scale atmospheric transport on chemistry and amount of atmospheric precipitation in the center of European Russia. Russian Meteorology and Hydrology 35: 253. https://doi.org/10.3103/S1068373910040023

- The evolution of island and continental territories of the European sector of the Arctic under the influence of natural and anthropogenic factors: an interim report on research (2016) Arkhangelsk, 184 pp.

- The evolution of island and continental territories of the European sector of the Arctic under the influence of natural and anthropogenic factors: an interim report on research (2017) Arkhangelsk, 142 pp.

- Vinogradova AA (2000) Anthropogenic pollutants in the Russian Arctic atmosphere: sources and sinks in spring and summer. Atmospheric Environment 34(29-30): 5151-5160. https://doi.org/10.1016/S1352-2310(00)00352-6

- Vinogradova AA (2015) Distant evaluation of atmospheric pollution influence on the remote territories. Izvestiya, Atmospheric and Oceanic Physics 51: 712. https://doi.org/10.1134/ S0001433815070099

- Vinogradova AA, Ivanova YuA (2017) Heavy metals in the atmosphere over the northern coast of eurasia. Interannual Variations in Winter and Summer 53(7): 711-718. https://doi. org/10.1134/S000143381707009X

- Vinogradova AA, Kotova EI (2016) Metals in atmospheric precipitations and in lake waters in the north-west of Russia. 
Ecological Chemistry 25(1): 52-61. https://elibrary.ru/item. asp?id=26005348

- Vinogradova AA, Maksimenkov LO, Pogarskii FA (2008) Atmospheric transport of anthropogenic heavy metals from the Kola Peninsula to the surfaces of the White and Barents seas. Izvestiya, Atmospheric and Oceanic Physics 44: 753. https:// doi.org/10.1134/S0001433808060091

- Vinogradova AA, Ponomareva TY (2012) Atmospheric transport of anthropogenic impurities to the Russian arctic (1986-
2010). Atmos. Ocean Opt. 25: 414. https://doi.org/10.1134/ S1024856012060127

M-02-0203-09 (2009) Methods for measuring the mass fraction of sodium, silicon, calcium, titanium, vanadium, chromium, barium, manganese, iron, nickel, copper, zinc, strontium, lead, zirconium, molybdenum, aluminum, magnesium in powder samples of soil and bottom sediments by X-ray method with using Energy Dispersive X-ray Fluorescence Spectrometer of the Shimadzu. St. Petersburg. 